\title{
THE SHELF AND COASTAL WATERS OFF SOUTHERN BRAZIL *
}

(Received 20/9/1960)

\author{
Ingvar Emílsson
}

\section{INTRODUCTION}

The waters off the coast of Southern Brazil have not received much attention by the larger oceanographical expeditions which have worked in the South Atlantic Ocean. It is true that three of the transoceanic sections, worked by the "Meteor" Expedition (1925-1927) reach up to this part of the coast of South America. On the other hand, it is well known that the vast work laid down by this expedition, more than 30 years ago, was intended to provide a general picture of the circulation of the water masses in the Atlantic Ocean and in particular of the deeper layers.

Data from other expeditions which occasionally have headed their way along the western side of the ocean to and from Antarctic waters do not add much to our knowledge concerning the region under consideration here since both seasonal and geographical variations take place on a larger scale than formerly has been realized.

The purpose of the present note is to describe and discuss some of the most outstanding features of the waters off the coast of Southern Brazil on the basis of data collected during the last five years by the Oceanographic Institute in São Paulo. The most extensive and complete series of data from the whole region were collected on three cruises carried out by means of ships

This paper was delivered at the 1959, International Oceanographic Congress New York.

Publ. nv 144 do Inst. Ocean. da USP. 
placed at the disposal of the Institute by the Brazilian Navy, during the months of February-March, June and November 1956. On these cruises a total of 112 stations were occupied, covering an area which extends from Cabo Frio (Lat. $24^{\circ} \mathrm{S}$ ) to Rio Grande (Lat. $34^{\circ} \mathrm{S}$ ) and $200-300$ n.m. off the coast. The hydrographic data as well as charts showing track and stations' position have been published elsewhere (Emílsson, 1956).

\section{WATER MASSES}

To characterize water masses only the T-S relations will be used here. Our attention is first turned to the warm and saline water which occupies the surface layer of the South Atlantic tropical zone with its maximum temperature and salinity well above $25^{\circ} \mathrm{C}$ and $36.5^{\circ} \%$, respectively, in the area situated east of the Bahia coast. It has been shown by A. Defant (1937) that this water type, whose characteristics are due to the intensive radiation and excess of evaporation above precipitation as well as low rate of transport of water across the tropical thermocline, penetrates in all directions from this area and appears as a layer of maximum salinity at depths between the surface and $100 \mathrm{~m}$ in the adjacent regions.

A part of this water-type is carried to the south by the Brazil Current where it contributes, by mixture with waters of lower salinity and temperature, to the formation of a water mass having salinity above $36 \%$ and temperature higher than $20^{\circ} \mathrm{C}$. The water mass so defined will be referred to as South Atlantic Tropical Water (S.A.T.) or simply Tropical Water.

On its way southwards the Tropical Water gradually loses its heat to the atmosphere. Consequently the density increases and the water mass extends to greater depths thus forming the northern zone of the Subtropical Convergence which, at the western side of the ocean, fluctuates between the $30^{\text {th }}$ and $40^{\text {th }}$ parallel approximately. Together with this cooling mechanism, the Tropical Water is mixed with water of lower salinity and temperature from the south. The result of this process is a water mass of salinity between $36 \%$ and $35 \%$ and temperature ranging from $20^{\circ} \mathrm{C}$ to $10^{\circ} \mathrm{C}$. This water mass will be called Subtropical Water. It is a part of the South Atlantic Central Water as defined by Sverdrup et al. (1942). 


\section{THE BRAZIL CURRENT SOUTH OF THE ABROLHOS}

Before going further in the survey of the water masses involved, it is useful to discuss briefly the flow of the Brazil Current.

On its way southwards the Current passes to shallow banks which extend several hundred miles to the east of the Abrolhos Region (Lat. $18^{\circ} \mathrm{S}$ ). This obstacle deviates a branch of the Current to the east and also disturbs the vertical stratification by bringing water from greater depths to the surface. The presence of this water, rich in nutritive elements, near the surface is doubtless the reason for the relatively flourishing marine life found in this area. The data collected by the Brazilian Navy during the IGY indicate the occurrence of large eddies to the south of this region and these may be a consequence of the irregular bottom topography found there.

From the Cabo São Tomé (Lat. $22^{\circ} \mathrm{S}$ ) the Current becomes more regular and the distribution of temperature and salinity indicate that the main branch follows the edge of the continental shelf, which at these latitudes extends about 50 n.m. off the coast. The data show that the Brazil Current reaches its highest velocities over the edge of the shelf. The inner border of the Current is easily detected by the marked difference in color observed when crossing from the greenish and less transparent water over the shelf into the deep-blue and clear water from the north. This is especially noted in the area to the east and south of Cabo Frio. The western limit of the Current is also indicated by the difference in salinity and temperature between the Tropical Water and the Shelf Water. In order to bring out this feature we have selected the distribution of salinity at 10 meters, represented on Fig. 1. The contour of 200 meters has also been plotted on the map to show the approximate extension of the continental shelf. It is seen that the shelf grows gradually wider southwards, extending over 100 n.m., off Santos and 150 n.m., off Rio Grande. In the northern and central part of the region the 36 and 36.5 isohalines follow the $200 \mathrm{~m}$ contour closely. The tongue of high salinity delimited by the isohalines indicate very well the main flow of the Brazil Current along the edge of shelf. It is seen that the two isohalines had practically the same position in the section "Santos-SE" in November as in March 1956. The same section was also repeated in June the same year. On this occasion water of salinity higher than $36 \%$ was found much closer to the coast. This was also the case in June 1954, on the occasion of a short 
cruise with the privately owned yacht "Igaraty", when water of salinity slightly above $36 \%$ was encountered only 30 n.m., off Santos.

From the data at hand it may thus be concluded that the western limit of the Brazil Current stays relatively stable along the edge of the continental shelf during the summer months (September-March), while in the winter season the flow turns more irregular giving rise to eddies which may advance towards the coast. Dynamic calculations of relative current velocities as well as experiments with drift bottles also show that the Current becomes rather weak and irregular during winter while its flow is steadier, swifter and concentrated along the edge of the shelf, where dynamic calculations have given values of relative velocities up to $40 \mathrm{~cm} / \mathrm{sec}$, in summer.

\section{THE COASTAL WATERS}

The peculiar features of the coastal zone of this region is that it receives relatively small contributions of fresh water from land, in spite of the tropical or sub-tropical regime of precipitation over the Continent on these latitudes. This is due to the circumstance that all larger rivers flow westwards into the Paraná River Basin and finally end up in the La Plata River. Thus the drainage area is limited to the eastern slopes of the Serra do Mar and the narrow coastal plain. The influence of water from land is therefore rather small, in spite of fairly high rainfall with smali seasonal variations over the eastern side of the mountain range.

An exception to this rule is found in the southernmost part of the region, where great amounts of fresh water enter the coastal area through the outlet of Lagoa dos Patos near the town of Rio Grande (Lat. $32^{\circ} \mathrm{S}$ ). The waters from the La Plata River are also present in this area, which can be seen from the low salinity indicated in Fig. 1. Further north, a zone of strong salinity transition is present. This is also the case concerning the distribution of temperature. This transition zone may thus be considered as the western extremity of the Subtropical Convergence, the position of which suffers frequent and abrupt changes on account of the strong drift currents flowing over the shallow and wide continental shelf. It may, however, be considered a rule that the transition zone is situated in front of the coast of Uruguay during the summer months, while it may reach as far north as Santa Catarina Island in winter. 
In the transition zone some of the richest shoals of fish (mainly Corvina - Micropogon furnieri) and best trawling grounds are found. The localization and survey of this front is therefore of considerable practical importance for the fishing industry.

From Fig. 1 it is seen that the salinity off the coast of Santa Catarina is relatively high. This is partly due to the low contingents of fresh water from land as well as to the greater influence of Tropical Water since the Brazil Current flows closer to the coast in this area. Further to the north, in front of the States of Paraná, São Paulo and Rio de Janeiro salinity under $34.5 \%$ is frequently found in the coastal area. In front of the open coast, far from estuaries and closed bays, water of salinity under $33 \%$, has, however, never been observed.

Since the extension as well as the salinity of the water near the coast depends upon the run-off of fresh water and also upon the intensity by which it mixes with the waters situated at greater distance from the coast, it should be expected that the volume of the coastal water is increased during the summer on account of increased rainfall and also because of lesser influence of the Tropical Water close to the coast at this time of the year, as previously mentioned.

It must, however, be remembered that the data at hand are by no means sufficient to permit any general conclusion as to the seasonal variations in the coastal waters. To overcome this deficiency, fortnightly observations of salinity, temperature and oxygen as well as quantitative sampling of plankton are being carried out by the staff of this Institute at three fixed stations, situated at 3, 7.5, and 15 n.m. to the east of Bom Abrigo Island (Lat. $\left.25^{\circ} 7^{\prime} \mathrm{S}\right)$. These observations have been made regularly since January 1958 and it is hoped that the continuation of such routine observations and samplings will elucidate many features of physical and biological nature of which we have until now little knowledge.

\section{THE SHELF WATER AND ITS ORIGIN}

Over the continental shelf we encounter water of salinity $35 \%$ to $36 \%$ (Fig. 1). At first glance it might seem that this characteristic results from lateral mixing between the coastal water of lower salinity and the saltier water found over the outer zone of the shelf. The vertical sections indicate, however, that 


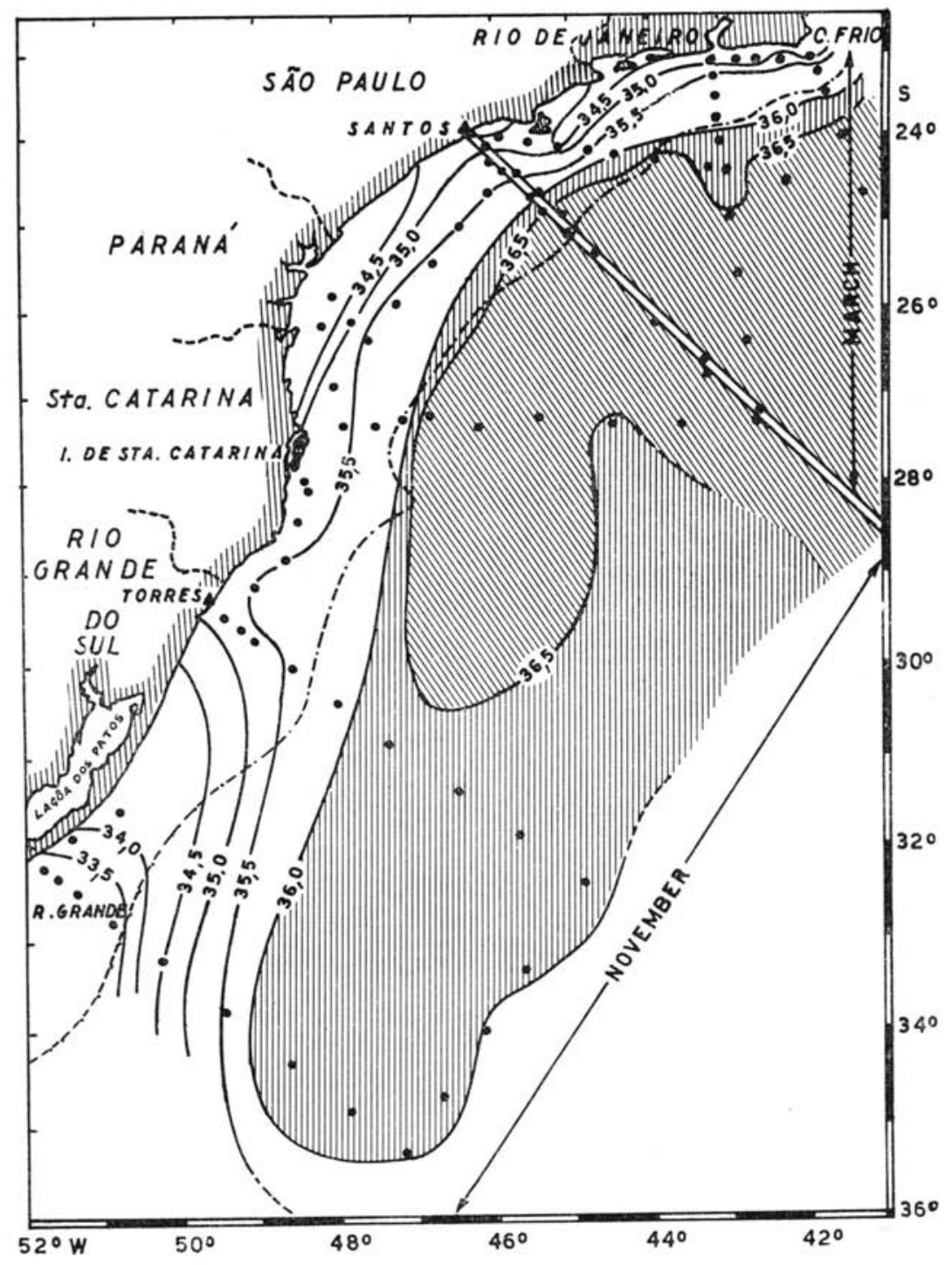

Fig. 1 - Distribution of salinity in the 10 meters plan. Stations taken by Cv. "Solimōes" in 1956. March, northern part; November, central and southern part. 
this water is strongly influenced by the Subtropical Water. In order to show the relation between this last mentioned water mass and the one found over the shelf we have selected, as an example, a vertical section extending $150 \mathrm{n} . \mathrm{m}$. to the southeast of Cabo Frio, shown on Fig. 2. It is readily seen that there is a close connection between the Subtropical Water and the water mass occupying the surface layer immediately to the west of the Brazil Current.

The distribution of salinity, temperature and density suggests the presence of upwelling similar to the well known ascension of water off the coast of California, West Africa, Peru, etc. In these regions the process can be attributed to the effect of prevailing winds blowing from the coast, or parallel to it, with the consequence that the surface water is drawn away from the coast and replaced by waters from below.

Now, it must be borne in mind that the distribution of density found in the vertical section (Fig. 2) is a consequence of the southward-flowing Brazil Current in virtue of the well established correlation between the density distribution in a vertical section and the relative current perpendicular to the same section. Therefore the available data make it possible to compute the relative velocities of the horizontal currents but do not permit any statement whatsoever about the occurrence of the vertical movement, or upwelling, as one might believe at first glance. The wind field, as presented on the Pilot Charts of U.S. Hydrographic Office indicates, for the Cabo Frio region, a wind blowing from NE with an average force of 4 Beaufort during most of the year. Doubtless a wind of this nature may push the surface waters away from the coast and thus give place to upwelling in its immediate vicinity, although it could hardly be held responsible for any intense ascension of water near the outer zone of the shelf.

The studies on a possible process of upwelling, in this area, called for the search of another factor which could maintain the process, since the common prevailing wind mechanism seems inadequate to account for the present case.

The salinity inversion found in the outer part of the section is a characteristic feature of the Tropical Water. The vertical stability is therefore entirely due to the downwards decreasing temperature. Now, the water found in the central part of the section is of higher density but of lower salinity and temperature than the southward flowing Tropical Water, and an eventual heat- 


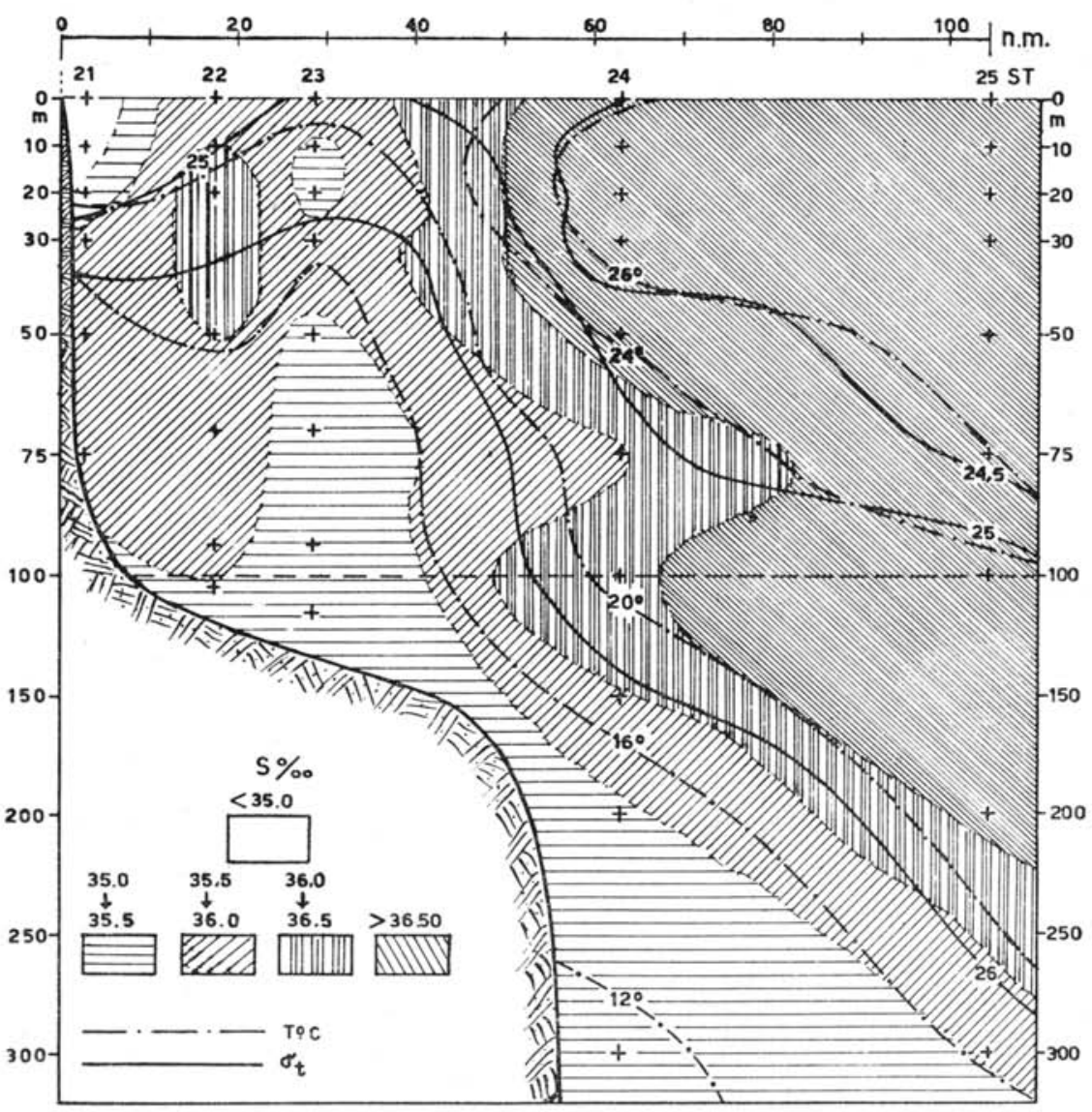

Fig. 2 - Section from Cabo Frio to SSE, showing the distribution of salinity, temperature and density. Cv. "Solimőes" - March 5th, 1956.

ing of the surface layer, where the colder water exists, will disturb the dynamical balance of the relative current.

A closer examination of this situation indicates that an upwelling maintained by thermohaline processes may occur along the western side of the Brazil Current in a zone extending from the State of Espírito Santo (Lat. $20^{\circ} \mathrm{S}$ ), to the State of Paraná (Lat. $26^{\circ} \mathrm{S}$ ), having a relative maximum of intensity in the region of Cabo Frio and reaching its annual maximum in summer. The thermohaline mechanism of upwelling can then briefly be described as follows: the water of relatively low salinity and temperature, 
which occupies the zone immediately to the west of the Brazil Current, is heated by solar radiation so that its density becomes equal to or lower than that of the Tropical Water situated further to the east (Fig. 3). This change in density of the surface water will disturb the dynamical stability of the Current, causing heated water to flow out of the region in the surface layer, giving place to heavier water from below, which in turn suffers the same change in temperature and density, and so on.

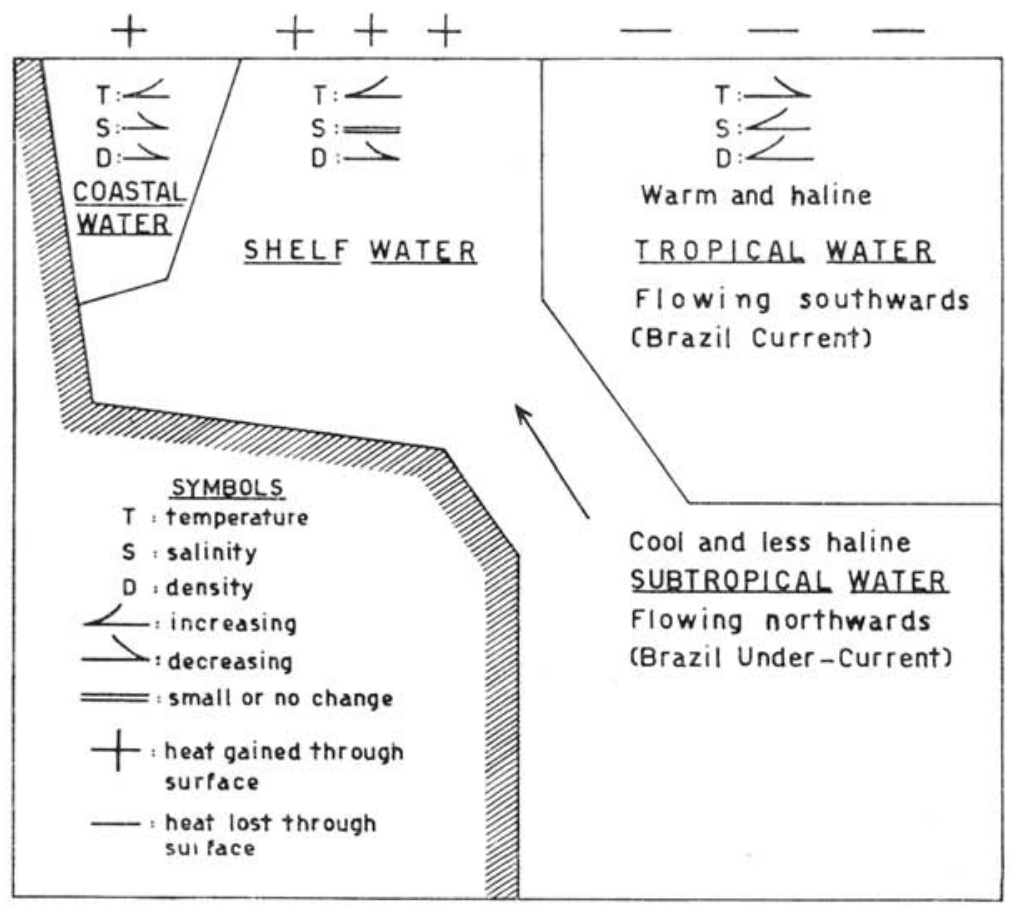

Fig. 3 - Diagram on arbitrary scale illustrating the mechanism of thermohaline upwelling. The distribution of watermasses correspond approximately to that found in the Section Cabo Frio-SSE (Fig. 2).

It might be argued why the warmer water should not increase in temperature by the same amount as the colder water, since the conditions, as concerns the radiation from sun and sky, may be considered to be the same over both water masses. It is also to be expected that the absorption of the radiating energy will be 
the same in both cases. In view of the Stefan-Boltzmann law of thermal radiation it can, however, be concluded that the backradiation from the colder water is less intense than from the warmer water which must, indeed, on these latitudes, have reached a radiation equilibrium against the sky. Further it can be supposed that the loss of heat by evaporation is lower from the colder water since the vertical transport of humidity is limited by the greater stability of the air immediately above the colder surface. As the evaporation is more intense from the warmer surface, under otherwise equal conditions, the increase of salinity, and therefore also of density, is greater in this water mass. Although of minor importance, this factor may be added to the two already mentioned.

From the considerations above it seems likely that there is an ascension of Subtropical Water in considerable quantity along the middle zone of the continental shelf. The water mass found in this area, the Shelf Water, is thus formed by mixing of Subtropical, Tropical and Coastal Water as well as through heating by solar radiation.

For a quantitative examination of such thermohaline process of upwelling more data are needed on net radiation, evaporation, air and water turbulence, etc. Any mathematical model, where equations of thermodynamics should be introduced will be of theoretical value only, as long as data of this nature are not available.

It may finally be noted that thermohaline upwelling of the kind here described may occur in other regions of the oceans, where similar conditions are present or even where cold surface currents flow to lower latitudes as for example the Benguela Current off Africa and the Humboldt Current off the coast of Chile. Under such conditions the surface water will decrease in density as it flows towards lower latitudes and, for the same reasons as already mentioned, be carried away from the coast and replaced by water from below.

\section{ACKNOWLEDGEMENTS}

The author wishes to acknowledge his indebtedness to staff members of Instituto Oceanográfico who have collaborated in the collecting and processing of data on which the present paper is based. 
Thanks are especially due to Dr. Marta Vannucci for reading and discussing the manuscript, to $\mathrm{Mr}$. Eduardo Ramos for mending the text, and to Mr. Irineu Marcondes for the preparation of drawings.

\section{S U M M A R Y}

The data collected on three oceanographic cruises undertaken in 1956 indicate that the main branch of the Brazil Current flows southwards along the continental slope, where it reaches maximum velocity, and further, that a well defined limit is found between the warm and saline tropical water from the north and that situated over the central part of the shelf. This is especially the case during the summer months (October-March). Below the Brazil Current a water layer of lower salinity and temperature is found. This water mass is formed near the western extremity of the Subtropical Convergence where it sinks and flows northwards to reappear near or at the surface in an area situated between the lighter, south-flowing, tropical water, and the coastal water. Such a distribution of density across the Current is to be expected in view of the dynamics of ocean currents. There are, however, evidences which indicate the occurrence of upwelling from moderate depths, in particular near Cabo Frio where the prevailing winds from NE drive the surface waters offshore. It is further suggested that the upwelling is maintained by a thermohaline mechanism as the density of the cold and low salinity water is decreased by heating from solar radiation. In order to maintain dynamic stability, the heated water must consequently flow out of the area and be replaced by water from below which in turn suffers the same decrease of density, and so on. Such mechanism might, together with prevailing winds, be responsible for permanent or periodic upwelling near other regions in the tropical and subtropical zone of the oceans where salinity decreases with depth.

\section{RES UMO}

Os dados obtidos no decorrer de três cruzeiros oceanográficos realizados em 1956 demonstram que o ramo principal da Corrente do Brasil corre em direção sul ao longo do talude continental, onde ela atinge a máxima velocidade. Observa-se, por outro lado, um limite bem definido entre as águas tropicais, quentes e mais salgadas, vindas do norte, e aquelas que recobrem a zona central do platô continental. Isto é particularmente observado durante os meses de verão (outubro-março). Debaixo da Corrente do Brasil encontramos águas de baixa temperatura e salinidade. Esta massa de água se forma perto da extremidade ocidental da Convergência Subtropical, onde ela afunda e retorna para o norte para reaparecer na superfície - ou em camadas imediatamente inferiores - em uma área situada entre águas tropicais mais densas que correm para o sul e águas costeiras. Tal distribuição de densidade através da Corrente do Brasil está de acôrdo com a dinâmica das correntes oceânicas.

Há, além disso, indícios que evidenciam a formação de um "upwelling" proveniente de pequenas profundidades, particularmente na região de Cabo Frio, onde os ventos dominantes de $\mathrm{NE}$ forçam as águas de superfície em direção ao largo. De conformidade com a opinião do autor, êste "upwellling" é mantido por um mecanismo termo-halino causado pela radiação solar que, aquecendo a água ressurgente (fria e de baixa salinidade), provoca a dimi- 
nuição de sua densidade. Por conseguinte, para que a estabilidade dinâmica possa ser mantida, águas aquecidas devem se dirigir para o largo, dando lugar a águas de profundidade que, por sua vez, sofrem a mesma diminuição de densidade. Isto se dá de forma contínua. Tal mecanismo deve ser, a par com os ventos dominantes, o fator predominante de um "upwelling" permanente e periódico nas vizinhanças de outras zonas tropicais e subtropicais dos oceanos, onde a salinidade diminui com a profundidade.

\section{R EFER E N C E S}

\section{Defant, A.}

1936. Die Troposphäre. Deutsche Atlantische Expedition "Meteor" 1925-1927. Wiss. Erg., Bd. VI, Teil I, 3. Lief., p. 289-411.

EMílsSon, I.

1956. Relatório e resultados físico-químicos de três cruzeiros oceanográficos em 1956. Contr. Avul. Inst. Ocean., Ocean. Física, n. ${ }^{\circ}$ 1, 70p. ilus.

Sverdrup, H. U., Johnson, M. W., Fleming, R. H.

1942. The oceans. New York, Prentice-Hall, Inc. x, 1087 p., 265 figs. 7 charts. 